\title{
A new indicator on the impact of large-scale circulation on wintertime particulate matter pollution over China
}

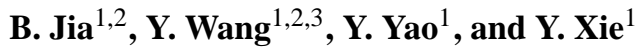 \\ ${ }^{1}$ Ministry of Education Key Laboratory for Earth System Modeling, Center for Earth System Science, Tsinghua University, \\ Beijing, China \\ ${ }^{2}$ Department of Marine Sciences, Texas A\&M University at Galveston, Galveston, TX, USA \\ ${ }^{3}$ Department of Atmospheric Sciences, Texas A\&M University, College Station, TX, USA
}

Correspondence to: Y. Wang (yxw@tsinghua.edu.cn)

Received: 23 April 2015 - Published in Atmos. Chem. Phys. Discuss.: 14 July 2015

Revised: 23 September 2015 - Accepted: 14 October 2015 - Published: 27 October 2015

\begin{abstract}
Extreme particulate matter (PM) air pollution of January 2013 in China was found to be associated with an anomalous eastward extension of the Siberian High (SH). We developed a Siberian High position index (SHPI), which depicts the mean longitudinal position of the $\mathrm{SH}$, as a new indicator of the large-scale circulation pattern that controls wintertime air quality in China. This SHPI explains $58 \%$ (correlation coefficient of 0.76 ) of the interannual variability of wintertime aerosol optical depth (AOD) retrieved by MODIS over North China (NC) during 2001-2013. By contrast, the intensity-based conventional Siberian High index (SHI) shows essentially no skill in predicting this AOD variability. On the monthly scale, some high-AOD months for $\mathrm{NC}$ are accompanied with extremely high SHPIs; notably, extreme PM pollution of January 2013 can be explained by the SHPI value exceeding 2.6 times the standard deviation of the 2001-2013 January mean. When the SH extends eastward, thus higher SHPI, prevailing northwesterly winds over $\mathrm{NC}$ are suppressed not only in the lower troposphere but also in the middle troposphere, leading to reduced southward transport of pollution from NC to South China (SC). The SHPI hence exhibits a significantly negative correlation of -0.82 with MODIS AOD over SC during 2001-2013, although the robustness of this correlation depends on that of satellite-derived AOD. The suppressed northwesterly winds during high-SHPI winters also lead to increased relative humidity (RH) over NC. Both the wind and RH changes are responsible for enhanced PM pollution over NC during the high-SHPI winters.
\end{abstract}

\section{Introduction}

January 2013 saw persistent and severe haze outbreaks in China, with monthly mean fine particulate matter $\left(\mathrm{PM}_{2.5}\right)$ levels exceeding $130 \mathrm{\mu g} \mathrm{m}^{-3}$ at 28 cities in 16 provinces. Previous studies have identified certain features of meteorological conditions during this month that are partly responsible for such extreme pollution. An abnormal high at $500 \mathrm{hPa}$ was found over east China which suggested a weakened East Asian trough with suppressed vertical mixing (Zhang et al., 2014; Yang et al., 2013). In the lower atmosphere, surface winds were much weaker during severe haze episodes (Zhang et al., 2014; Y. S. Wang et al., 2014). The average height of planetary boundary layer (PBL) over North China Plain was about $50 \%$ lower during the haze episodes than that during non-episode days (Huang et al., 2014; L. T. Wang et al., 2014). Ambient relative humidity (RH), an important meteorological parameter affecting secondary aerosols formation and their hygroscopic growth (Sun et al., 2013; Y. X. Wang et al., 2014), has also been reported to be significantly higher during the haze periods (Huang et al., 2014; Y. S. Wang et al., 2014).

The aforementioned studies did not address the question whether extreme air pollution of January 2013 over China is connected with the anomaly of large-scale circulation patterns at a temporal scale broader than that of the episodic cases. The East Asian monsoon is the most prominent feature of large-scale circulation patterns over the Eurasia continent. While the summer monsoon has been shown to play a significant role in regulating the interannual variation of 
air pollution over China (L. Zhang et al., 2010; Zhu et al., 2012), few studies have examined the wintertime association between the variability of monsoon-related large-scale circulation patterns and air pollution. As the most important largescale circulation patterns in winter, the Siberian High has a significant influence on winter climate in Northern Eurasia, East Asia, and even the whole Northern Hemisphere (e.g., Cohen et al., 2001; Gong et al., 2002; Chernokulsky et al., 2013). The sea level pressure difference between the Siberian High over the Asian continent and the Aleutian Low over North Pacific causes strong northwesterly winds along the east flank of the Siberian High and the East Asian Coast, which characterizes the East Asian winter monsoon (Chang et al., 2012). Wu et al. (2002) reported a significant positive correlation between the intensity of the Siberian High and the East Asian winter monsoon on the interannual to interdecadal timescales. The variation of the Siberian High may have an impact on wintertime air quality over east China, for example by ways of influencing large-scale wind fields and local meteorological conditions which control pollutant transport and transformation.

This study investigates the possible connections between wintertime $\mathrm{PM}_{2.5}$ in eastern China and large-scale circulations on the interannual scale during 2001-2013. Because long-term in situ observations of surface $\mathrm{PM}_{2.5}$ are not available in China, we use satellite-derived aerosol optical depth (AOD) as a proxy to represent the distribution and variability of atmospheric aerosols. The paper is organized as follows. Section 2 describes the data used in the analysis. In Sect. 3, we analyze the anomalous meteorological conditions of January 2013 and define our study regions. Section 4 examines the relationship of the Siberian High and AOD over China, and develops an index to represent Siberian High variability which is able to explain the interannual variations of AOD. In Sect. 5, we discuss the robustness of the index we develop and compare it with other existing meteorological indices that may influence wintertime air quality in China.

\section{Data}

\subsection{Aerosol optical depth}

AOD products from satellites have been used to infer surface $\mathrm{PM}_{2.5}$ concentrations at scales ranging from urban to regional and to global (Liu et al., 2007; H. Zhang et al., 2009; Lee et al., 2011; Hu et al., 2014; Boys et al., 2014; van Donkelaar et al. 2014; Xie et al., 2015). To circumvent data scarcity of longer-term in situ surface measurement over China, here we used AOD retrieved from the Moderate Resolution Imaging Spectroradiometer (MODIS) sensor aboard both NASA EOS-Terra and Aqua satellite as the proxy data to represent the distribution and variability of $\mathrm{PM}_{2.5}$ air quality. Terra and Aqua are both polar-orbiting satellites launched in December 1999 and May 2002, respectively. They have been providing data every 1 to 2 days since February 2000 (Terra) and July 2002 (Aqua). MODIS retrieves aerosol properties in seven wavelengths from 0.47 to $2.13 \mu \mathrm{m}$ and separate algorithms are applied over land and ocean (Tanré et al., 1997; Remer et al., 2005; Levy et al., 2007). To improve the retrieval over bright-reflecting source regions, the Deep Blue AOD algorithm was developed using multiple narrowband channels at near-UV wavelengths (Hsu et al., 2004). Although the AOD uncertainty over land $( \pm 0.05 \pm 0.2 \times$ AOD) is higher than that over ocean $( \pm 0.03 \pm 0.05 \times \mathrm{AOD})(\mathrm{Re}-$ mer et al., 2005; Chu et al., 2002), previous comparisons of MODIS AOD and ground-based AOD measurements from AErosol RObotic NETwork (AERONET) sites over land have shown tight correlations between the two, indicating that the MODIS AOD product is capable of providing quantitative information on the spatial and temporal variations of AOD over land (Levy et al., 2010; Prados et al., 2007).

Previous studies have indicated good correlations between the MODIS AOD and surface $\mathrm{PM}_{2.5}$ concentrations over selected sites in China (Wang et al., 2003; Xie et al., 2015). Here we used the MODIS level-3 monthly gridded AOD $(550 \mathrm{~nm})$ data (Version 5.1) from December 2000 to February 2013 with a $1^{\circ} \times 1^{\circ}$ resolution. The AOD values over bright surfaces were replaced by the Deep Blue aerosol retrieval $(550 \mathrm{~nm})$ at the same grid.

To verify the robustness of our analysis using MODIS AOD, we also analyzed level-3 monthly gridded AOD from Multi-angle Imaging SpectroRadiometer (MISR) aboard of Terra. The MISR standard AOD products have a $0.5^{\circ} \times 0.5^{\circ}$ resolution at $558 \mathrm{~nm}$ for 2001-2013. MODIS has a large number of spectral bands, while MISR has the multi-viewangle capabilities (Lyapustin et al., 2007).

\subsection{Reanalysis data}

The meteorological variables used to explore the mechanism behind the variations of SH and AOD are obtained from National Centers for Environmental Prediction (NCEP) reanalysis (Kalnay et al., 1996), including sea level pressure (SLP), relative humidity (RH), geopotential heights, and winds. The NCEP/NCAR reanalysis data provide a historical record of more than 50 years (Kistler et al., 2001) and are available on the $2.5^{\circ} \times 2.5^{\circ}$ grid globally.

To verify the robustness of NCEP reanalysis in characterizing large-scale circulation patterns, we also analyzed the reanalysis data from European Centre for Medium-Range Weather Forecasts (ECMWF) Re-analysis Interim (ERAInterim), the latest global atmospheric reanalysis produced by ECMWF (Simons et al., 2007). NCEP and ERA-Interim are the two widely used reanalysis products with relatively long periods. 

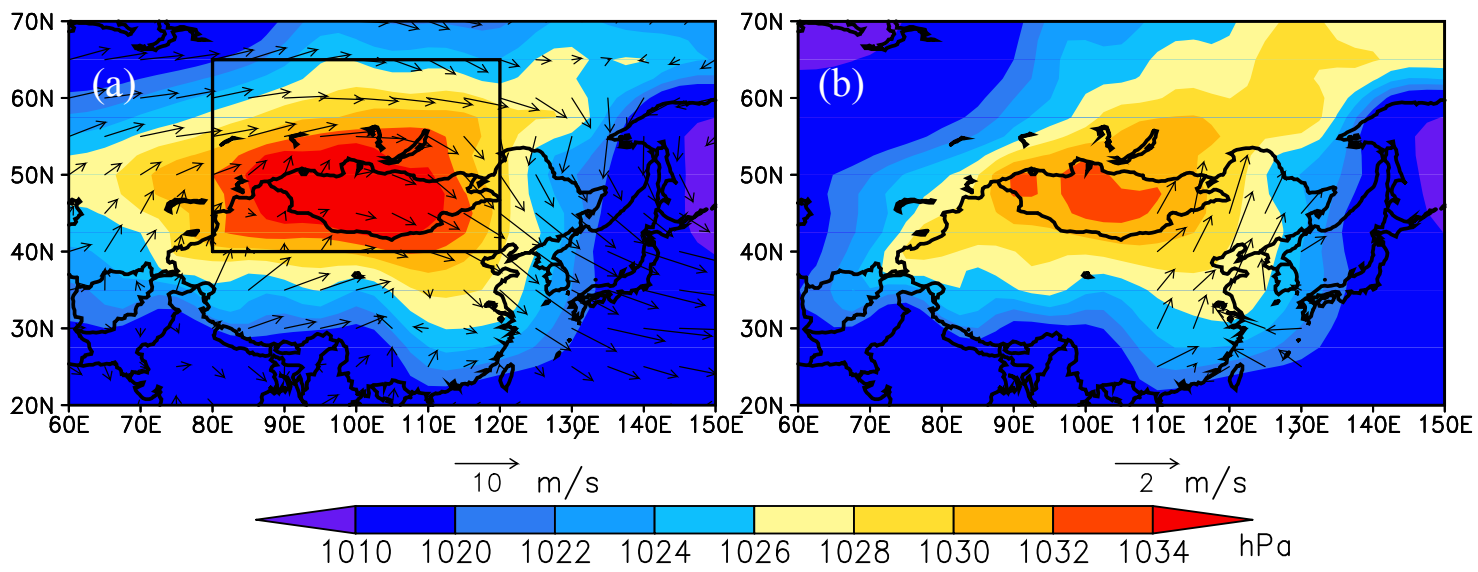

Figure 1. (a) Multi-year (2001-2012) mean January SLP (shaded) and $850 \mathrm{hPa}$ wind fields (vectors); (b) January 2013 SLP (shaded) and the anomalies $850 \mathrm{hPa}$ wind fields (vectors); the black rectangle outlines the region used in the definition of conventional Siberian High intensity. The length of the wind vectors indicates wind speed $\left(\mathrm{m} \mathrm{s}^{-1}\right)$.

\section{Study domains}

Figure 1a shows the mean January SLP and $850 \mathrm{hPa}$ wind fields during 2001-2012 from NCEP. The Siberian High $(\mathrm{SH})$ is a semi-permanent anticyclone high-pressure system centered over Mongolia and eastern Siberia (black rectangle in Fig. 1a) that is formed by radiative cooling in winter. Driven by the pressure gradient between the Siberian High and the Aleutian Low over northwest Pacific, the prevailing winds over east China are northwesterly in winter. Figure $1 \mathrm{~b}$ displays the January 2013 SLP and the $850 \mathrm{hPa}$ wind anomalies compared to the 2001-2012 mean. The SLP was significantly lower over Mongolia in January 2013, indicating a significantly weaker Siberian High and consequently a weaker East Asian winter monsoon during this month. This anomalous SLP distribution of January 2013 is associated with anomalous southerly winds in the lower atmosphere over east China (Fig. 1b) and coincident with higher temperatures and RH (not shown), which all present as favorable meteorological conditions for the buildup and recirculation of air pollutants over this region (Sun et al., 2013; Zhang et al., 2014; Y. S. Wang et al., 2014). Given the anomalously weak SH in January 2013, which was a heavily polluted month in China, we hypothesize that $\mathrm{SH}$ variability is a key indicator of the variability in large-scale circulation patterns which control the variability of wintertime PM pollution over east China.

To test this hypothesis, we investigated if significant association exists in winter between the SH variability and regional PM pollution over China on a longer-term scale (2001-2013), using MODIS-derived AOD as an indicator of aerosol levels. Figure 2a shows the 13-year mean winter AOD distribution over China and Fig. 2b displays the mean change of AOD from 2001-2006 to 2007-2013. North China $\left(30-42^{\circ} \mathrm{N}, 115-123^{\circ} \mathrm{E}\right.$; black rectangle in Fig. $\left.2 \mathrm{~b}\right)$ is among the regions with highest aerosol loadings and largest increases of AOD during the two averaging periods. Accord- ing to current emission inventories, the emissions of $\mathrm{SO}_{2}$, $\mathrm{NO}_{x}$, and $\mathrm{NH}_{3}$ from North China accounts for $25-35 \%$ of total emissions in China, and $\mathrm{SO}_{2}$ emissions from North China have increased faster than those from other regions of China (Lu et al., 2010; Y. Zhang et al., 2010; Q. Zhang et al., 2009). Therefore, North China (NC) is defined as the source region of aerosols. According to the climatological $850 \mathrm{hPa}$ wind field (Fig. 1a), the wintertime pollution outflow from $\mathrm{NC}$ follows southeastwards pathways and is expected to influence air quality over South China (SC), which is shown as the red rectangle in Fig. $2 \mathrm{~b}\left(22-30^{\circ} \mathrm{N}, 110-120^{\circ} \mathrm{E}\right)$. Here SC is defined as the domestic receptor region of $\mathrm{NC}$ aerosols in winter.

\section{Development of the Siberian High position index and its association with AOD}

\subsection{Index development}

Figure 3 depicts the time series of winter AOD averaged over $\mathrm{NC}$, showing a significant increase in AOD from about 0.5 in 2001 to about 0.8 in 2013. A linear regression of the time series gives a trend of $1.5 \%$ year $^{-1}(r=0.65, p<0.05)$. Since the meteorological variables and atmospheric circulation patterns are not expected to drive such a large linear trend during this period, this AOD trend is mostly likely caused by increasing anthropogenic emissions over this region (Lu et al., 2010, 2011; Zhang et al., 2012; Streets et al., 2009). The departure of each winter's AOD from that depicted by the linear trend is assumed to represent the influence of meteorology. The years in which winter AOD lies above $30 \%$ of the residual confidence interval of the linear trend line are referred to as the high-AOD winters (including 2001, 2003, 2007, 2008, 2013) and those below $30 \%$ of the residual confidence interval as the low-AOD winters (including 2002, 2004, 2006, 

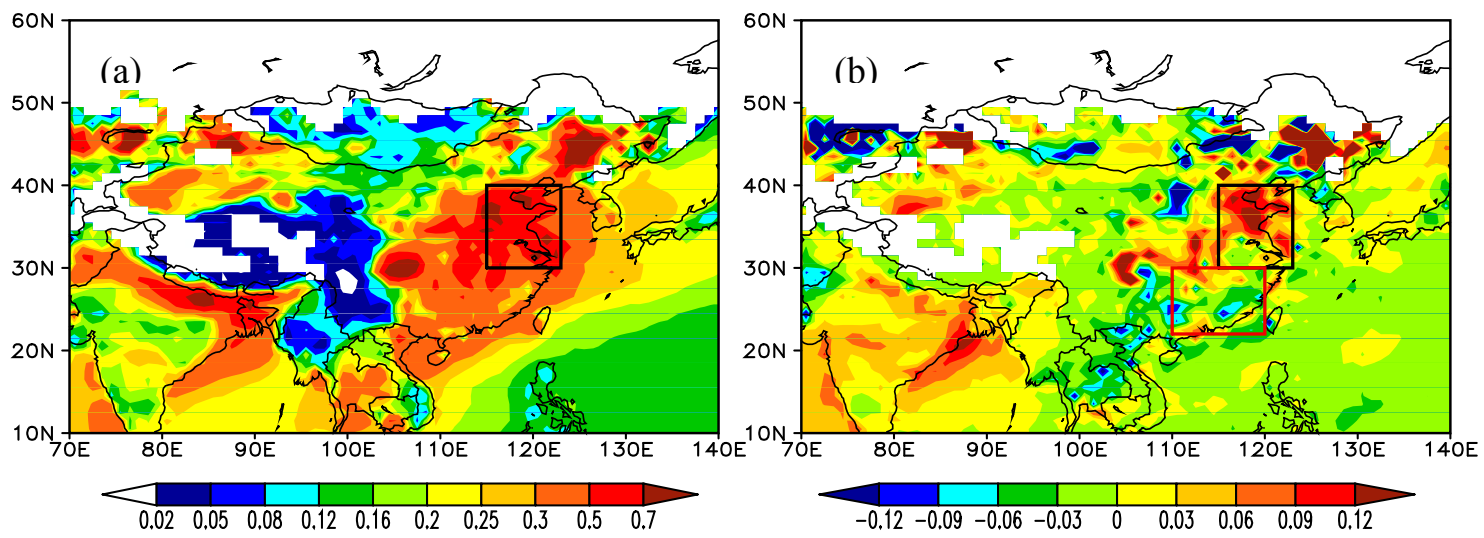

Figure 2. (a) Multi-year mean winter AOD from 2001-2013; (b) the change of winter mean AOD between 2007-2013 and 2001-2006 (2007-2013 minus 2001-2006). The black rectangle outlines North China (NC); the red rectangle outlines South China (SC).

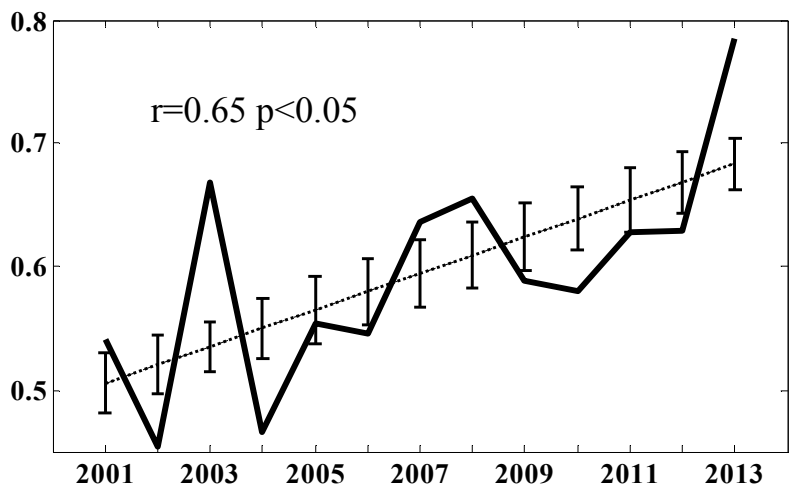

Figure 3. Time series of winter mean AOD over North China (solid thick line) and the fitted linear regression line (dotted thin line). The insert shows the correlation coefficient $(r)$ and significance of the linear regression. The vertical thin line indicates the residual confidence interval of the linear regression slope $(\alpha=0.7)$.

$2009,2010,2012)$. Since the high- or low-AOD is defined relative to the trend line, the corresponding high- or lowAOD winters are expected to be driven by the interannual variability of meteorology.

Mean meteorological conditions between the high- and low-AOD winters were compiled and compared to identify any significant differences in large-scale circulation patterns between them. The differences in winter-mean SLP and $850 \mathrm{hPa}$ wind fields are shown in Fig. 4 (high-AOD winters minus low-AOD winters). Surprisingly, Fig. 4 does not reveal any significant decrease of SLP from low-AOD to high-AOD winters over Mongolia where the climatological center of the Siberian High is located (cf. Fig. 1a). Instead, significant changes of SLP are located over west of Mongolia (negative differences) and over Japan (positive differences). The highAOD winters also have a stronger component of southeasterly winds at $850 \mathrm{hPa}$ over North China. This change of wind directions not only suppresses the northwesterly flow that

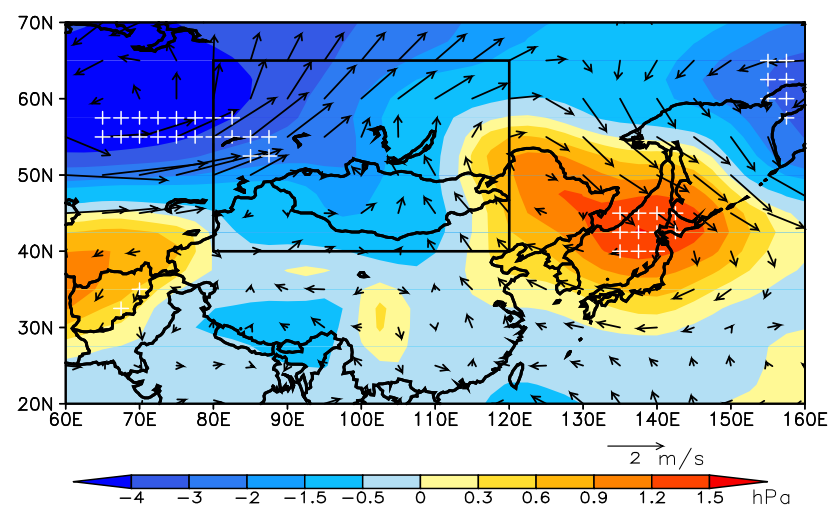

Figure 4. Difference of SLP (shaded, hPa) and $850 \mathrm{hPa}$ wind vectors $\left(\mathrm{m} \mathrm{s}^{-1}\right)$ between high- and low-AOD winters; areas with white pluses are differences at the $10 \%$ significance level; the black rectangle outlines the region used in the definition of conventional SHI. The length of the wind vectors indicates wind speed $\left(\mathrm{m} \mathrm{s}^{-1}\right)$.

brings cleaner continental background air, but also reduces the transport of pollution from NC to SC, both of which lead to higher pollution levels over NC.

The index widely used in the literature to describe the $\mathrm{SH}$ variability is the Siberian High intensity (SHI), defined as the mean SLP over northern Mongolia between $80-120^{\circ} \mathrm{E}$ and $40-65^{\circ} \mathrm{N}$ (black rectangle in Fig. 1a and 4) (Jeong et al., 2011; Hasanean et al., 2013). However, as shown by Fig. 4, there is no significant difference in SLP over northern Mongolia between the high- and low-AOD winters, suggesting that this conventional index of SH may not be able to explain the interannual variability of PM over North China. As an example, Fig. 5 compares winter SLP and $850 \mathrm{hPa}$ wind fields between 2003 (a high-AOD winter) and 2004 (a lowAOD winter). While winter-mean AOD over NC was significantly higher in 2003 (0.68) than that in 2004 (0.45), the SHI was almost the same between the two winters. The noticeable difference, however, is that the high-pressure isobars 


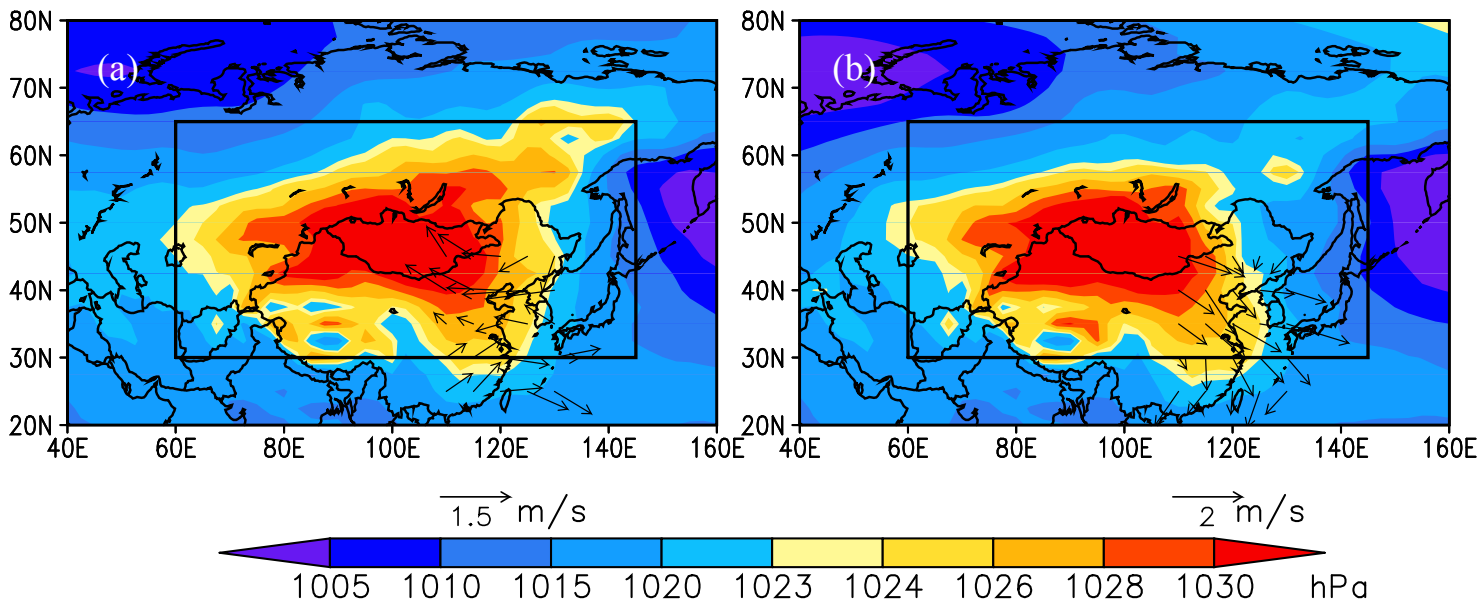

Figure 5. Distribution of winter SLP (shaded) and anomalous (minus 13-year mean) $850 \mathrm{hPa}$ wind fields (vector) in (a) 2003, and (b) 2004; the black solid rectangle outlines the region used in the definition of SHPI. The length of the wind vectors indicates wind speed ( $\mathrm{m} \mathrm{s}^{-1}$ ).

in the 2003 winter extended further east over the continent than those in the 2004 winter. Through linear regression, we found a poor correlation between SHI and detrended wintermean AOD over NC (Fig. 6a), with SHI explaining only $4 \%$ of the AOD variance. There is no significant $(p<0.05)$ trend in SHI during 2001-2013.

Figure 4 manifests the displacement of the high SLP center during the high-AOD winters from northern Mongolia where the conventional SHI is defined. Figure 5 further illustrates that the main difference in SH between the two specific winters of largely varying AODs lies in its spatial extension. Given this feature, we further hypothesized that the position of the Siberian High is a more important factor than its intensity in terms of affecting PM concentrations over NC. We thus proposed a Siberian High position index (SHPI) as the weighted mean of the longitudes of all the grids within the $1023 \mathrm{hPa}$ isobar over the broad region of $60-145^{\circ} \mathrm{E}$ and 30 $65^{\circ} \mathrm{N}$ (black rectangle in Fig. 5). The SHPI is defined by Eq. (1):

$\mathrm{SHPI}=\frac{\sum\left(P_{\mathrm{i}} \times L_{i}\right)}{\sum P_{i}}$

where $L_{i}$ is the longitude of any eligible grid $i$ within the $1023 \mathrm{hPa}$ isobar and the definition domain, and $P_{i}$ is the SLP of the corresponding grid $i$. The unit of SHPI is degree in longitude. Our definition of SHPI is similar to the longitude index of SH defined by Hou et al. (2008), but differs with regards to the region over which SHPI is calculated. They defined the index as the weighted mean longitudes of all the grids within the $1023 \mathrm{hPa}$ isobar which may extend westward to Europe and northward to the Arctic. Our definition of SHPI limits the spatial domain over which the $1023 \mathrm{hPa}$ isobar is considered in the SHPI calculation because of our focus on East Asia and particularly China (Fig. 5). The 20012013 time series of winter SHPI is displayed in Fig. 6b (black line) and the wintertime mean SHPI during this period is $98.9^{\circ} \mathrm{E}$. A larger SHPI indicates that the center of the Siberian High is located further east of its normal position. Referring back to Fig. 5, the 2003 winter has a significantly higher value of SHPI $\left(102.3^{\circ} \mathrm{E}\right)$ than that of 2004 $\left(\mathrm{SHPI}=96.3^{\circ} \mathrm{E}\right)$; so does the AOD over NC but not SHI (cf. Fig. 6a).

Figure $6 \mathrm{~b}$ shows the time series of winter-mean SHPI and NC AOD from 2001 to 2013. They exhibit a positive correlation of 0.39 , which is not significant due to the confounding effect of the increasing trend in AOD. Since the focus here is on variability, the AOD time series were detrended by removing any significant linear trend (detrended AOD) and the SHPI time series were normalized by their climatological mean and standard deviation. As shown in Fig. 6c, the detrended NC AOD and normalized SHPI display a strong correlation of $0.76(p<0.01)$, which means that the positionbased SHPI captures $58 \%$ of the interannual variance in winter AOD over NC. This indicates that on the interannual scale, winter AOD over NC can be better explained by SHPI, an index of the SH position, than the conventional SHI, an index of the SH intensity. According to Hou et al. (2008), the longitude index and intensity index of the SH may not be significantly correlated. In support of this point, we found the SHI and SHPI have a weak correlation of only -0.32 during the study period (Fig. S1 in the Supplement).

Figure 6d displays the time series of normalized SHPI and detrended NC AOD on the monthly scale. The corresponding raw data prior to the detrending and normalization are provided in Fig. S2. Here the normalization of SHPI is conducted separately for November, December, and January to retain its intraseasonal variability. At the monthly scale, the correlation between normalized SHPI and detrended NC AOD is also significant at $0.45(p<0.01)$. Some extremely high values of monthly AOD over NC show clear associa- 

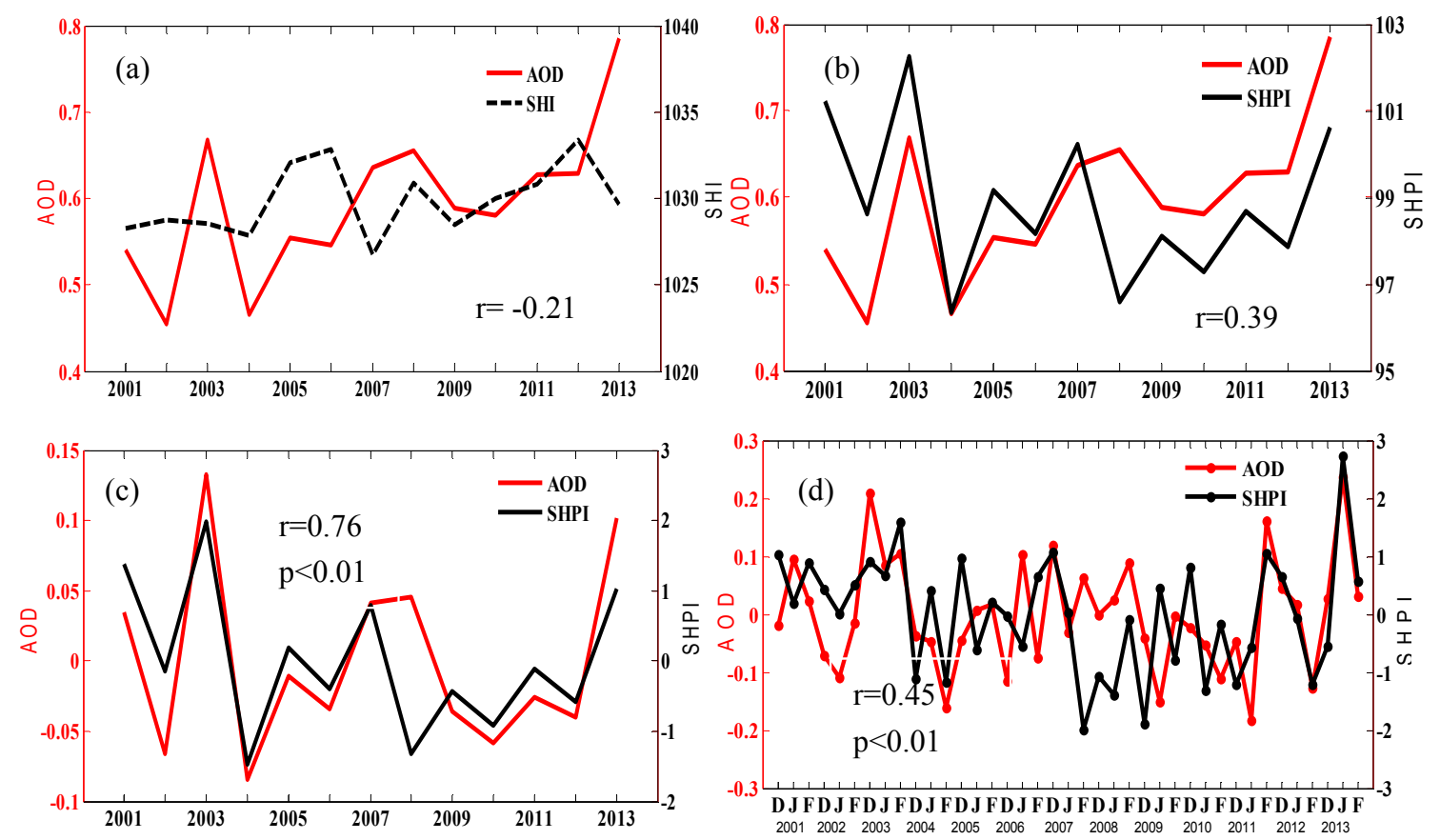

Figure 6. Time series of wintertime AOD over North China (red lines) with (a) SHI and (b) SHPI during 2001-2013. (c) Same as (b), but for detrended NC AOD and normalized SHPI. (d) Detrended NC AOD and normalized SHPI for each winter month (December, January, February) during 2001-2013.

tions with higher values of SHPI. Taking January 2013 as an example, which has the highest AOD over NC among all the 39 winter months studied here, the SHPI of that month is also the highest $\left(106.5^{\circ} \mathrm{E}\right)$, lying 2.6 times the standard deviation away from the 2001-2013 January mean $\left(99.8^{\circ} \mathrm{E}\right)$. This association indicates that the anomalous feature of the Siberian High in January 2013 was not only the weakening of its strength (cf. Fig. 1b) but also its more eastward extension, the latter being the primary factor contributing to high PM levels over NC. Another example is February 2011. Both AOD and SHPI of that month are among the highest values of the study period (Figs. 6d and S2). We thus conclude that the SHPI indicator of the SH variability is able to explain extremely high PM pollution over NC on the monthly scale.

\subsection{Mechanism}

To understand the mechanistic connection between SHPI and winter AOD over NC, we examine in this section how the SHPI variability is linked with the change of large-scale circulation patterns using the NCEP reanalysis data which span 30 years (1982-2011). The years with extremely high SHPI (beyond one standard deviation of the mean) in winter are defined to be high-SHPI years and those below one standard deviation of the mean as low-SHPI years. Figure 7a displays the climatological distribution of $850 \mathrm{hPa}$ wind fields during 1982-2011. The northwesterly winds larger than $5 \mathrm{~m} \mathrm{~s}^{-1}$ over North China and Japan indicate the strong influence of the Siberian High and East Asian winter monsoon. The area covered by the prevailing northwesterly winds and the mean speed of those winds exhibit interannual variability that correlates with SHPI to some extent. For example, the winter of 1990 has the highest SHPI $\left(105.9^{\circ} \mathrm{E}\right)$ during the 30-year study period and that of 2004 has the lowest SHPI $\left(96.3^{\circ} \mathrm{E}\right)$. As shown in Fig. S3, the area covered by northwesterly winds larger than $5 \mathrm{~m} \mathrm{~s}^{-1}$ is smaller in 1990 than that in 2004, and the average wind speed over that area is also smaller in 1990. On average, $850 \mathrm{hPa}$ wind speeds over $\mathrm{NC}$ are about 0.5 to $1 \mathrm{~m} \mathrm{~s}^{-1}$ lower during the high-SHPI winters than during the low-SHPI years (Fig. 7b). Table 1 summarizes wintertimemean zonal and meridional wind speeds over $\mathrm{NC}$ at different vertical levels for the 30-year average, high-SHPI average, and low-SHPI average. In the high-SHPI winters, both zonal and meridional wind speeds are lower not only at $850 \mathrm{hPa}$ but also at the upper levels. Lower wind speeds are conducive for pollution accumulation over the source region, which partly contributes to higher AOD in the high-SHPI winters. To further illustrate the connections between SHPI and wind changes, Figure $7 \mathrm{c}$ depicts the spatial distribution of correlation coefficients between SHPI and surface RH from 1982 to 2011. SHPI shows a significant positive correlation with $\mathrm{RH}$ over $\mathrm{NC}$, indicating enhanced water vapor convergence over NC in the high-SHPI winters. This positive correlation arises because weaker northerly winds lead to reduced transport of dry air masses from the cold Siberian landmass, compensated by enhanced transport of moist air masses through the anomalous southerly winds. Higher RH 

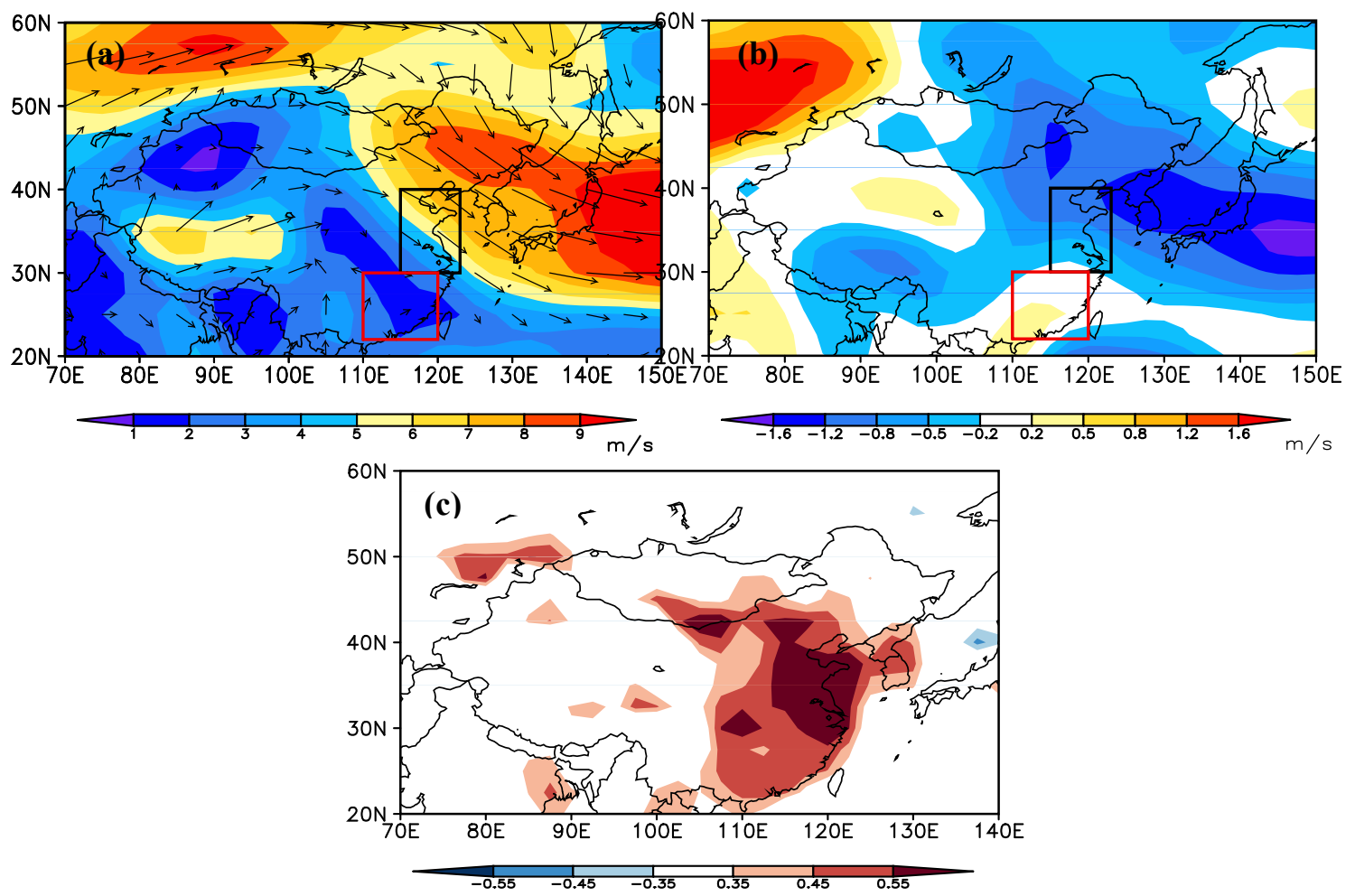

Figure 7. Geographic distributions of (a) multi-year (1982-2011) mean winter $850 \mathrm{hPa}$ wind direction (vector) and wind speed (shaded), (b) difference of wind speed between high-SHPI year mean and low-SHPI year mean $\left(\mathrm{m} \mathrm{s}^{-1}\right)$, and (c) winter interannual correlation coefficients of SHPI with relative humidity (colored areas are correlations above the $5 \%$ significance level).

Table 1. Mean zonal $(U)$ and meridional $(V)$ wind speeds over NC at different pressure levels $(850,700$ and $500 \mathrm{hPa})$ during all winters (1982-2011), the high-SHPI winters, and the low-SHPI winters. The high- and low-SHPI winters are defined as the winters with the SHPI value lying outside of one standard deviation above or below the mean, respectively. Unit: $\mathrm{m} \mathrm{s}^{-1}$.

\begin{tabular}{lcccccc}
\hline & \multicolumn{2}{c}{$850 \mathrm{hPa}$} & \multicolumn{2}{c}{$700 \mathrm{hPa}$} & \multicolumn{2}{c}{$500 \mathrm{hPa}$} \\
\cline { 2 - 7 } & $U$ & $V$ & $U$ & $V$ & $U$ & $V$ \\
\hline All winters (1982-2011) & 4.18 & -3.06 & 10.94 & -3.22 & 23.30 & -3.17 \\
High-SHPI winters & 3.83 & -2.67 & 10.39 & -2.66 & 21.58 & -2.33 \\
Low-SHPI winters & 4.26 & -3.18 & 11.23 & -3.17 & 24.24 & -2.94 \\
\hline
\end{tabular}

during the high-SHPI winters leads to higher mass concentrations and extinction of aerosols as a result of hygroscopic growth of aerosol species (Mu et al., 2014; Tai et al., 2010). Although higher SHPI is always associated with lower northwesterly wind and higher RH over $\mathrm{NC}$, local wind speed or $\mathrm{RH}$ itself is not as good an indicator as SHPI in explaining the interannual variation of $\mathrm{NC} \mathrm{AOD.} \mathrm{One} \mathrm{explanation} \mathrm{is} \mathrm{that}$ SHPI represents the combined effects of large-scale circulation change on local meteorological conditions. In addition, systematic errors have been found for lower-level wind fields from NCEP reanalysis (Shi et al., 2006).
To verify the above analysis of the mechanism, we tested the utility of SLP over Japan (SLPJ, defined over $130-145^{\circ} \mathrm{E}$ and $40-50^{\circ} \mathrm{N}$ ) as an alternative indicator of the large-scale circulation in explaining the interannual variations of AOD over NC. The reason why the SLPJ is used for comparison is because the high-AOD winters also feature significant positive changes of SLP over Japan (cf. Fig. 4). The time series of SLPJ is shown in Fig. S4. SLPJ shows a positive correlation with NC AOD and explains $38 \%$ of the variance in detrended NC AOD (Fig. S4a). By comparison, SHPI explains $58 \%$ of the variance of detrended NC AOD. SLPJ also correlates well with SHPI (Fig. S4b), which indicates that in the high-SHPI years the eastward extension of the SH leads to an increase of SLP over Japan and as a result SLPJ is not independent from SHPI. The anomalously high SLP over Japan influences the $\mathrm{PM}$ level over NC by reducing the prevailing northwesterly winds and increasing RH over NC, which is consistent with the mechanism provided above.

To summarize, the SHPI indicator developed here is able to capture the interannual variations of winter-mean and monthly-mean NC AOD to a large extent. Comparing to the climatology, $850 \mathrm{hPa}$ wind speeds over $\mathrm{NC}$ during the highSHPI years are suppressed by $13 \%$ and the surface relative humidity is enhanced by $12 \%$ as a result of the eastward extension of the SH. Since the suppressed wind speed is unfa- 
vorable for the dispersion of air pollution and higher surface relative humidity enhances secondary aerosol formation and hygroscopic growth, both factors lead to higher PM levels over NC in the high-SHPI years.

\subsection{AOD variability in South China}

Our above analysis suggests that the suppression of prevailing northwesterly winds and the enhancement of surface $\mathrm{RH}$ are the key meteorological features during the high-SHPI winters. The implication of such conditions for wintertime $\mathrm{PM}$ over SC, the domestic receptor region of wintertime NC outflow, is not straightforward. On one hand, suppressed northwesterly winds are unfavorable meteorological conditions for the export of pollution from NC, which may lead to reduced PM levels over SC. On the other hand, the Siberian High variability is expected to have an influence on local meteorological conditions over SC. In this section, we examine the extent to which the SHPI indicator developed in the previous section can explain the interannual variability of AOD over SC.

Figure 8 displays the time series of winter mean AOD over SC from MODIS. The multi-year mean AOD over SC is about 0.4 , with a positive but not significant trend of increase of $0.13 \%$ year $^{-1}$. The two highest AOD winters for SC are 2004 (0.46) and 2008 (0.48), both corresponding to the lowest SHPI. The overall correlation between SC AOD and normalized SHPI is -0.82 , suggesting that SHPI explains $67 \%$ of the variance in SC AOD. In the high-SHPI winters, the meridional wind speed over $\mathrm{NC}$ is reduced by 17, 16 and $19 \%$ at 850,700 , and $500 \mathrm{hPa}$, respectively, compared to the low-SHPI winters (Table 1). The suppressed northerly winds over NC lead to the direct effect of reduced southward transport of pollution from $\mathrm{NC}$ to $\mathrm{SC}$, resulting in lower AOD over SC during the high-SHPI winters. Meanwhile, the $850 \mathrm{hPa}$ wind speeds over SC do not show a significant difference between the high-SHPI and low-SHPI winters (Fig. 7b). Although there is a $7.5 \%$ enhancement of surface relative humidity over SC during the high-SHPI years (Fig. 7c), the overall significantly negative correlation between SC AOD and SHPI indicate that the suppressed pollution transport from $\mathrm{NC}$ to $\mathrm{SC}$ is the dominant factor to explain the influence of SHPI on AOD over SC.

\section{Discussion}

To test the robustness of the relationship between AOD and SHPI developed above using MODIS AOD and NCEP reanalysis, we conducted the same analysis using AOD derived from MISR (MISR AOD) and SHPI derived from the ERA-Interim reanalysis (ERA SHPI). Table 2 compares the correlation coefficients derived using the different data sets. Significant positive correlations are consistently found between the SHPI and AOD over NC, regardless of the data

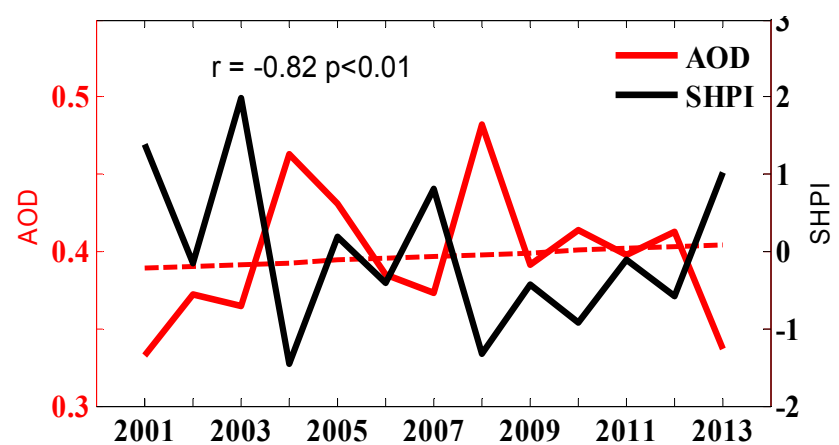

Figure 8. Time series of AOD over South China and normalized SHPI.

Table 2. Correlation coefficients between SHPI and AOD derived from different data sets: NCEP and ERA-Interim for SHPI, and MODIS and MISR for AOD.

\begin{tabular}{lcccc}
\hline & \multicolumn{2}{c}{ North China (NC) AOD } & \multicolumn{2}{c}{ South China (SC) AOD } \\
\cline { 2 - 5 } & MODIS & MISR & MODIS & MISR \\
\hline NCEP SHPI & 0.76 & 0.67 & -0.82 & 0.03 \\
ERA SHPI & 0.79 & 0.65 & -0.74 & -0.09 \\
\hline
\end{tabular}

sources from which the SHPI and AOD are derived. For example, the ERA SHPI has a correlation of 0.65 with MISR AOD over NC, compared to that of 0.76 between NCEP SHPI and MODIS AOD. This indicates the robustness of the SHPI indicator developed here with regard to explaining the interannual variability of AOD over NC. However, the correlation between SHPI and AOD over SC displays a dependence on the data source. The ERA SHPI has a similarly strong negative correlation with MODIS AOD over SC as the NCEP SHPI does, but neither NCEP SHPI nor ERA SHPI correlates well with MISR AOD over this region. This discrepancy can be partly explained by the inconsistency in the interannual variability of AOD between MODIS and MISR over SC. As shown in Fig. S5a, the correlation coefficient between the two AOD time series is only 0.07 over SC during 2001-2013, although neither shows a significant increasing trend. By comparison, the AOD time series from MODIS and MISR show a strong correlation of 0.7 over NC (Fig. S5b). Since SC has more cloud coverage than NC (Li et al., 2004), the inconsistency between MODIS and MISR over SC may lie in the different cloud-screening algorithms between MODIS and MISR. In addition, MISR has a lower sampling frequency than MODIS which may also lead to the inconsistency (Y. Zhang et al., 2010). Therefore, our conclusion on the association of SHPI with AOD variability over $\mathrm{SC}$ may require verification by later studies.

In addition to the conventional SHI, the number of cold air surges has been used as an indicator of the strength of the $\mathrm{SH}$ in winter. A cold air surge is an influx of unusually cold continental air from the Arctic Ocean and Siberia into the mid- 
dle or lower latitudes, and it is the main disastrous weather influencing China in the winter half-year. Niu et al. (2010) reported that the number of cold air surges decreased significantly from 1976 to 2007, which coincided with the increasing frequency of wintertime fog over eastern-central China. Varieties of definitions have been used for cold air surges, such as changes in surface temperature, surface pressure, and wind speed (Wang, B 2006). The definition of cold air surges we used is as follows. We took eight sites in North China (Jiuquan, Lanzhou, Beijing, Shenyang, Changchun, Haerbin, Xi' an, Ji'nan) and seven sites in South China (Nanjing, Hankou, Chengdu, Changsha, Guiyang, Fuzhou, Guangzhou). If the 15-site mean daily temperature keeps decreasing for 3 days and the overall magnitude of this temperature decrease is larger than $5^{\circ} \mathrm{C}$, it is considered a cold air surge. The number of cold air surges per winter during 2001-2013 is shown in Fig. S6, which explains less than $15 \%$ of the variance in the interannual variability of AOD over NC and SC. Thus, SHPI fares better than the number of cold air surges in explaining the interannual variability of AODs over different regions of China.

To summarize, through analyzing the anomalous meteorological conditions during January 2013, we have revealed not only the weakening of the strength of the Siberian High over Mongolia, but also its more eastward extension, the latter being the key factor contributing to high PM levels over NC. Thus, the SHPI depicting the mean longitudinal position of the Siberian High is developed, and this index captures $58 \%$ of the interannual variance in winter AOD over $\mathrm{NC}$ during 2001-2013. The SHPI is able to indicate the occurrence of high PM pollution levels over NC on the monthly scale; notably, the extreme PM pollution of January 2013 over NC is associated with an extremely high value of SHPI (above 2.6 times standard deviation of the 2001-2013 January mean). Mechanistic analysis indicates that high SHPI is often associated with suppressed prevailing northwesterly winds and higher relative humidity over NC, both of which are favorable for secondary formation and accumulation of PM over NC. The suppressed prevailing winds over NC also weaken the southward transport of pollution to SC, resulting in lower PM levels over SC. The positive correlations between NC AOD and SHPI also exist among different data sets we tested, including NCEP and ERA-Interim for SHPI and MODIS and MISR for AOD. However, the negative correlation between AOD and SHPI over SC is significant only when using AOD derived from MODIS and thus needs to be further confirmed.

The Supplement related to this article is available online at doi:10.5194/acp-15-11919-2015-supplement.
Acknowledgements. This research was supported by the National Key Basic Research Program of China (2013CB956603 and 2014CB441302) and the CAS Strategic Priority Research Program (grant no. XDA05100403). We thank Lu Shen for helpful discussion.

Edited by: S. Gong

\section{References}

Boys, B. L., Martin, R. V., van Donkelaar, A., MacDonell, R. J., Hsu, N. C., Cooper, M. J., Yantosca, R. M., Lu, Z., Streets, D. G., Zhang, Q., and Wang, S. W.: Fifteen-year global time series of satellite-derived fine particulate matter, Environ. Sci. Technol., 48, 11109-11118, doi:10.1021/es502113p, 2014.

Chang, C. P. and Lu, M. M.: Intraseasonal predictability of Siberian High and East Asian winter monsoon and its interdecadal variability, J. Climate, 25, 1773-1778, doi:10.1175/JCLI-D-1100500.1, 2012.

Chernokulsky, A., Mokhov, I. I., and Nikitina, N.: Winter cloudiness variability over northern Eurasia related to the Siberian High during 1966-2010, Environ. Res. Lett., 8, 045012, doi:10.1088/1748-9326/8/4/045012, 2013.

Chu, D. A., Kaufman, Y. J., Ichoku, C., Remer, L. A., Tanré, D., and Holben, B. N.: Validation of MODIS aerosol optical depth retrieval over land, Geophys. Res. Lett., 29, 1617, doi:10.1029/2001GL013205, 2002.

Cohen, J., Saito, K., and Entekhabi, D.: The role of the Siberian High in Northern Hemisphere climate variability, Geophys. Res. Lett., 28, 299-302, doi:10.1029/2000GL011927, 2001.

Gong, D. Y. and Ho, C. H.: The Siberian High and climate change over middle to high latitude Asia, Theor. Appl. Climatol., 72, 19, doi:10.1007/s007040200008, 2002.

Hasanean, H. M., Almazroui, M., Jones, P. D., and Alamoudi, A. A.: Siberian high variability and its teleconnections with tropical circulations and surface air temperature over Saudi Arabia, Clim. Dynam., 41, 2003-2018, doi:10.1007/s00382-012-1657-9, 2013.

Hou, Y. H., Yang, X. Q., Li, G., and Wang, Q.: Four indexes and their change rates Siberian High, Journal of Nanjing Institute of Meteorology, 31, 326-330, 2008 (in Chinese).

Hsu, N. C., Tsay, S. C., King, M. D., and Herman, J. R.: Aerosol properties over bright-reflecting source regions, IEEE T. Geosci. Remote, 42, 557-569, doi:10.1109/TGRS.2004.824067,2004.

Hu, X., Waller, L. A., Lyapustin, A., Wang, Y., and Liu, Y.: 10year spatial and temporal trends of $\mathrm{PM}_{2.5}$ concentrations in the southeastern US estimated using high-resolution satellite data, Atmos. Chem. Phys., 14, 6301-6314, doi:10.5194/acp-14-63012014, 2014.

Huang, K., Zhuang, G., Wang, Q., Fu, J. S., Lin, Y., Liu, T., Han, L., and Deng, C.: Extreme haze pollution in Beijing during January 2013: chemical characteristics, formation mechanism and role of fog processing, Atmos. Chem. Phys. Discuss., 14, 7517-7556, doi:10.5194/acpd-14-7517-2014, 2014.

Jeong, J. H., Ou, T., Linderholm, H. W., Kim, B. M., Kim, S.-J., Kug, J. S., and Chen, D.: Recent recovery of the Siberian High intensity, J. Geophys. Res.-Atmos., 116, D23102, doi:10.1029/2011JD015904, 2011. 
Kalnay, E., Kanamitsu, M., Kistler, R., Collins, W., Deaven, D., Gandin, L., Iredell, M., Saha, S., White, G., Woollen, J., Zhu, Y., Leetmaa, A., Reynolds, R., Chelliah, M., Ebisuzaki, W., Higgins, W. , Janowiak, J., Mo, K. C., Ropelewski, C., Wang, J., Jenne, R., and Joseph, D.: The NCEP/NCAR 40-year reanalysis project, B. Am. Meteorol. Soc., 77, 437-473, 1996.

Kistler, R., Collins, W., Saha, S., White, G., Woollen, J., Kalnay, E., Chelliah, M., Ebisuzaki, W., Kanamitsu, M., Kousky, V., Dool, H., Jenne, R., and Fiorino, M.: The NCEP-NCAR 50-year reanalysis: monthly means CD-ROM and documentation, B. Am. Meteorol. Soc., 82, 247-267, 2001.

Lee, H. J., Liu, Y., Coull, B. A., Schwartz, J., and Koutrakis, P.: A novel calibration approach of MODIS AOD data to pre$\operatorname{dict} \mathrm{PM}_{2.5}$ concentrations, Atmos. Chem. Phys., 11, 7991-8002, doi:10.5194/acp-11-7991-2011, 2011.

Levy, R. C., Remer, L. A., Mattoo, S., Vermote, E. F., and Kaufman, Y. J.: Second-generation operational algorithm: retrieval of aerosol properties over land from inversion of Moderate Resolution Imaging Spectroradiometer spectral reflectance, J. Geophys. Res.-Atmos., 112, D13211, doi:10.1029/2006JD007811, 2007.

Levy, R. C., Remer, L. A., Kleidman, R. G., Mattoo, S., Ichoku, C., Kahn, R., and Eck, T. F.: Global evaluation of the Collection 5 MODIS dark-target aerosol products over land, Atmos. Chem. Phys., 10, 10399-10420, doi:10.5194/acp-10-10399-2010, 2010.

Li, Y., Yu, R. C., Xu, Y. P., and Zhang, X. H.: Spatial Distribution and Seasonal Variation of Cloud over China Based on ISCCP Data and Surface Observations, J. Meteorol. Soc. Jpn., 82, 761773, doi:10.2151/jmsj.2004.761, 2004.

Liu, Y., Franklin, M., Kahn, R., and Koutrakis, P.: Using aerosol optical thickness to predict ground-level $\mathrm{PM}_{2.5}$ concentrations in the St. Louis area: a comparison between MISR and MODIS, Remote Sens. Environ., 107, 33-44, doi:10.1016/j.rse.2006.05.022, 2007.

Lu, Z., Streets, D. G., Zhang, Q., Wang, S., Carmichael, G. R., Cheng, Y. F., Wei, C., Chin, M., Diehl, T., and Tan, Q.: Sulfur dioxide emissions in China and sulfur trends in East Asia since 2000, Atmos. Chem. Phys., 10, 6311-6331, doi:10.5194/acp-106311-2010, 2010.

Lu, Z., Zhang, Q., and Streets, D. G.: Sulfur dioxide and primary carbonaceous aerosol emissions in China and India, 1996-2010, Atmos. Chem. Phys., 11, 9839-9864, doi:10.5194/acp-11-98392011, 2011.

Lyapustin, A., Wang, Y., Kahn, R., Xiong, J., Ignatov, A., Wolfe, R., Wu, A., Holben, B., and Bruegge, C.: Analysis of MODIS-MISR calibration differences using surface albedo around AERONET sites and cloud reflectance, Remote Sens. Environ., 107, 12-21, doi:10.1016/j.rse.2006.09.028, 2007.

$\mathrm{Mu}, \mathrm{Q}$. and Liao, H.: Simulation of the interannual variations of aerosols in China: role of variations in meteorological parameters, Atmos. Chem. Phys., 14, 9597-9612, doi:10.5194/acp-149597-2014, 2014.

Niu, F. Z., Li, Q., Li, C., Kwon-Ho, L., and Zhang, M. Y.: Increase of wintertime fog in China: potential impacts of weakening of the eastern Asian monsoon circulation and increasing aerosol loading, J. Geophys. Res.-Atmos., 115, D00k20, doi:10.1029/2009JD013484, 2010.

Prados, A. I., Kondragunta, S., Ciren, P., and Knapp, K. R.: GOES Aerosol/Smoke Product (GASP) over North America: compar- isons to AERONET and MODIS observations, J. Geophys. Res.Atmos., 112, D15201, doi:10.1029/2006jd007968, 2007.

Remer, L. A., Kaufman, Y. J., Tanré, D., Mattoo, S., Chu, D. A., Martins, J. V., Li, R.-R., Ichoku, C., Levy, R. C., Kleidman, R. G., Eck, T. F., Vermote, E., and Holben, B. N.: The MODIS aerosol algorithm, products, and validation, J. Atmos. Sci., 62, 947-973, doi:10.1175/JAS3385.1, 2005.

Shi, X. H., Xu, X., and Xie, L.: Realibility analysis if anomalies of NCEP/NCAR reanalysis wind speed and surface temperature in climate change research in China, J. Meteor. Res., 6, 709-722, 2006 (in Chinese).

Simmons, A., Uppala, S., Dee, D., and Kobayashi, S.: ERA-Interim: new ECMWF reanalysis products from 1989 onwards, ECMWF Newsletter, 110, 25-35, 2007.

Streets, D. G., Yan, F., Chin, M., Diehl, T., Mahowald, N., Schultz, M., Wild, M., Wu, Y., and Yu, C.: Anthropogenic and natural contributions to regional trends in aerosol optical depth, 1980-2006, J. Geophys. Res., 114, D00D18, doi:10.1029/2008JD011624, 2009.

Sun, Y., Wang, Z., Fu, P., Jiang, Q., Yang, T., Li, J., and Ge, X.: The impact of relative humidity on aerosol composition and evolution processes during wintertime in Beijing, China, Atmos. Environ., 77, 927-934, doi:10.1016/j.atmosenv.2013.06.019, 2013.

Tai, A. P. K., Mickley, L. J., and Jacob, D. J.: Correlations between fine particulate matter $\left(\mathrm{PM}_{2.5}\right)$ and meteorological variables in the United States: implications for the sensitivity of $\mathrm{PM}_{2.5}$ to climate change, Atmos. Environ., 44, 3976-3984, doi:10.1016/j.atmosenv.2010.06.060, 2010.

Tanré, D., Kaufman, Y. J., Herman, M., and Mattoo, S.: Remote sensing of aerosol properties over oceans using the MODIS/EOS spectral radiances, J. Geophys. Res.-Atmos., 102, 16971, doi:10.1029/96jd03437, 1997.

van Donkelaar, A. A., Martin, R. V., Brauer, M., and Boys, B. L.: Use of satellite observations for long-term exposure assessment of global concentrations of fine particulate matter, Environ. Health Persp., 123, 135-143, doi:10.1289/ehp.1408646, 2014.

Wang, J. and Christopher, S. A.: Intercomparison between satellitederived aerosol optical thickness and $\mathrm{PM}_{2.5}$ mass: implications for air quality studies, Geophys. Res. Lett., 30, 2095, doi:10.1029/2003gl018174, 2003.

Wang, B.: The Asian Monsoon, Springer, New York, 189 pp., 2006.

Wang, L. T., Wei, Z., Yang, J., Zhang, Y., Zhang, F. F., Su, J., Meng, C. C., and Zhang, Q.: The 2013 severe haze over southern Hebei, China: model evaluation, source apportionment, and policy implications, Atmos. Chem. Phys., 14, 3151-3173, doi:10.5194/acp-14-3151-2014, 2014.

Wang, Y. X., Zhang, Q. Q., Jiang, J., Zhou, W., Wang, B., He, K., Duan, F., Zhang, Q., Philip, S., and Xie, Y.: Enhanced sulfate formation during China's severe winter haze episode in January 2013 missing from current models, J. Geophys. Res.-Atmos., 119, 10425-10440, doi:10.1002/2013JD021426, 2014.

Wang, Y. S., Yao, L., Wang, L., Liu, Z., Ji, D., Tang, G., Zhang, J., Sun, Y., Hu, B., and Xin, J.: Mechanism for the formation of the January 2013 heavy haze pollution episode over central and eastern China, Sci. China Ser. D, 57, 14-25, doi:10.1007/s11430013-4773-4, 2014.

Wu, B. and Wang, J.: Winter Arctic oscillation, Siberian High and East Asian winter monsoon, Geophys. Res. Lett., 29, 1897, doi:10.1029/2002GL015373, 2002. 
Xie, Y. Y., Wang, Y., Zhang, K., Dong, W., Lv, B., and Bai, Y.: Daily estimation of ground-level $\mathrm{PM}_{2.5}$ concentrations over Beijing using $3 \mathrm{~km}$ resolution MODIS AOD, Environ. Sci. Technol., 49, 12280-12288, doi:10.1021/acs.est.5b01413, 2015.

Yang, K., Dickerson, R. R., Carn, S. A., Ge, C., and Wang, J.: First observations of $\mathrm{SO}_{2}$ from the satellite Suomi NPP OMPS: widespread air pollution events over China, Geophys. Res. Lett., 40, 4957-4962, doi:10.1002/grl.50952, 2013.

Zhang, H., Hoff, R. M., and Engel-Cox, J. A.: The relation between Moderate Resolution Imaging Spectroradiometer (MODIS) aerosol optical depth and $\mathrm{PM}_{2.5}$ over the United States: a geographical comparison by U.S. Environmental Protection Agency regions, JAPCA J. Air Waste Ma., 59, 13581369, doi:10.3155/1047-3289.59.11.1358, 2009.

Zhang, L., Liao, H., and Li, J.: Impacts of Asian summer monsoon on seasonal and interannual variations of aerosols over eastern China, J. Geophys. Res., 115, D00K05, doi:10.1029/2009JD012299, 2010.

Zhang, Q., Streets, D. G., Carmichael, G. R., He, K. B., Huo, H., Kannari, A., Klimont, Z., Park, I. S., Reddy, S., Fu, J. S., Chen, D., Duan, L., Lei, Y., Wang, L. T., and Yao, Z. L.: Asian emissions in 2006 for the NASA INTEX-B mission, Atmos. Chem. Phys., 9, 5131-5153, doi:10.5194/acp-9-5131-2009, 2009.
Zhang, Q., Geng, G. N., Wang, S. W., Richter, A., and He, K. B.: Satellite remote sensing of changes in $\mathrm{NO}_{x}$ emissions over China during 1996-2010, Chinese Sci. Bull., 57, 2857-2864, doi:10.1007/s11434-012-5015-4, 2012.

Zhang, Y. and Sun, Z.: Comparisons of MODIS and MISR aerosol optical thickness over eastcentral China, Journal of the Meteorological Sciences, 30, 48-54, 2010 (in Chinese).

Zhang, Y., Dore, A. J., Ma, L., Liu, X. J., Ma, W. Q., Cape, J. N., and Zhang, F. S.: Agricultural ammonia emissions inventory and spatial distribution in the North China Plain, Environ. Pollut., 158, 490-501, doi:10.1016/j.envpol.2009.08.033, 2010.

Zhang, R. H., Li, Q., and Zhang, R. N.: Meteorological conditions for the persistent severe fog and haze event over eastern China in January 2013, Sci. China Ser. D, 57, 26-35, doi:10.1007/s11430013-4774-3, 2014.

Zhu, J., Liao, H., and Li, J.: Increases in aerosol concentrations over eastern China due to the decadal-scale weakening of the East Asian summer monsoon, Geophys. Res. Lett., 39, L09809, doi:10.1029/2012GL051428, 2012. 